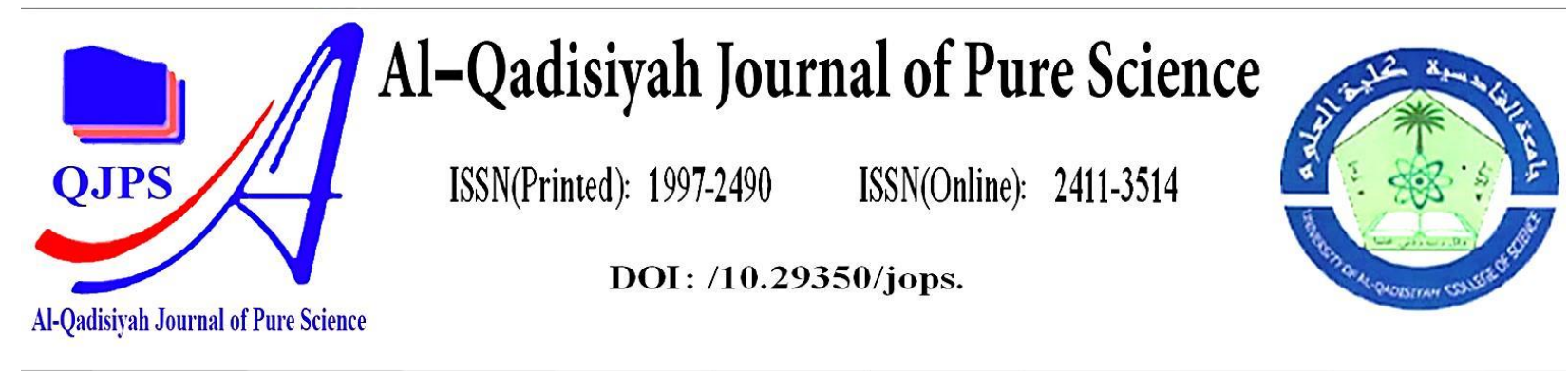

\title{
The first recording of the wilt of the Hendersonian branches on the Ficus sp (Ficus) in Iraq and its bio-control
}

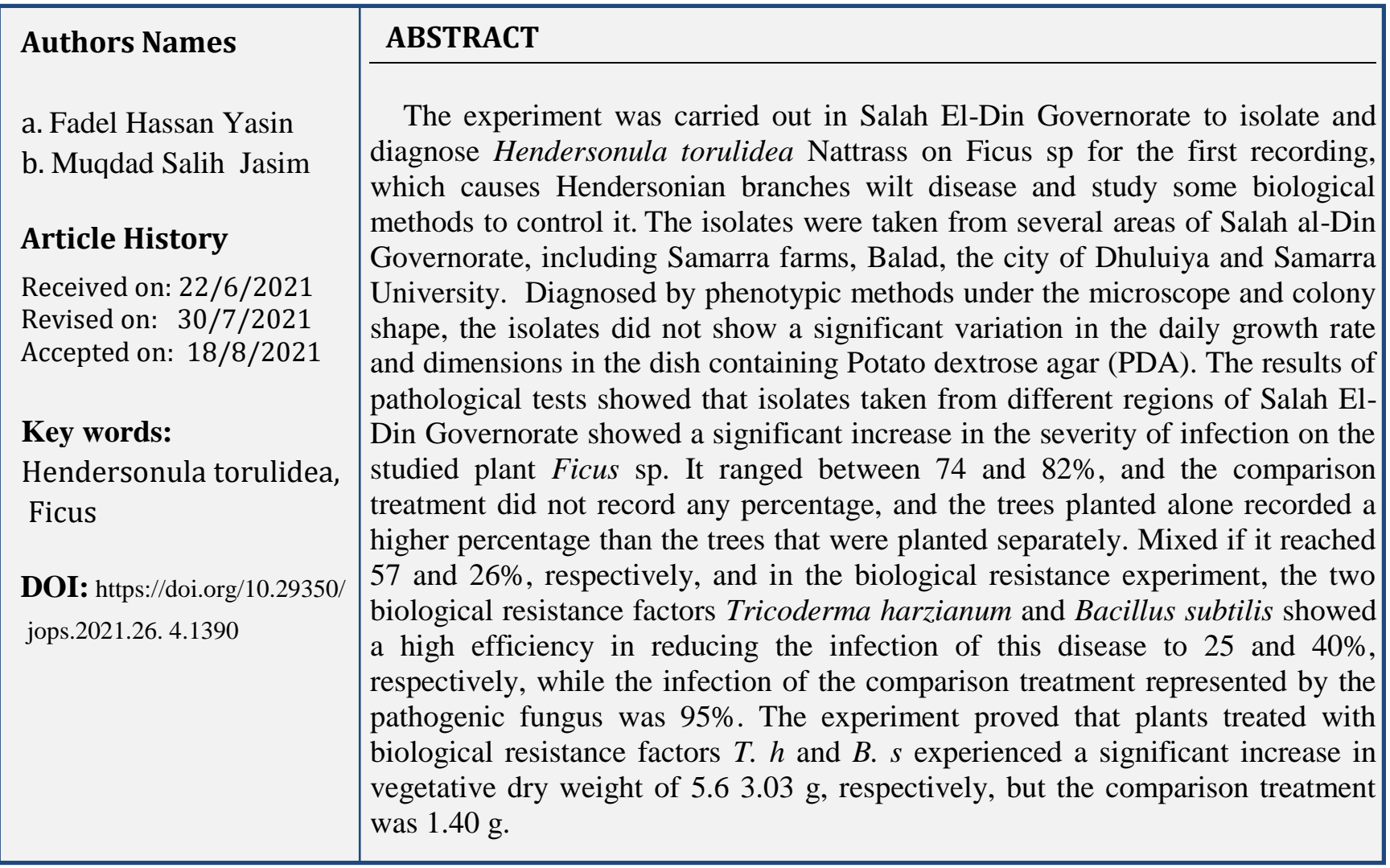

\section{1..Introduction}

The plant is an evergreen plant, where it is descended from the family and has economic importance in the production of wood in addition to the aesthetic area where it can be raised on geometric forms for the work of fences, fenders and labyrinths, as well as withstand high temperatures and humidity. It is a plant that enters joy in the soul when it is planted at the entrance to the house, but it is sensitive to sunlight and high temperature when pruning, so it gets sun blisters, which leads to injuries and falling leaves. Ficus plants suffer from a number of insect, bacterial and fungal pests, the latter being the most economically harmful because it leads to the death of the plant or the loss of part of it, which reduces its beauty and the destructive fungi of 
this wealth is the Hendersonula torulidea H.T. In the field visits, I decided to conduct this research and through microscopic examination and review of the sources found that the fungus

has not been studied before and has not been registered on Ficus in Iraq. In Iran, it has been studied in detail on the Phyx plant and the study was environmental physiological (19), (13). The disease was first recorded globally in Egypt in 1933 on the walnut trees (20) In Iraq, several studies have been conducted on the registration of the disease on different families such as grapes (20) and apples (6), (2), plant juniper in Nineveh. For the first time, the susceptibility of fungi to the production of toxic compounds was detected in agricultural media. The toxins have been isolated, diagnosed and their mechanism of effect (6). The first two types of toxins affect chlorophyll by holding the magnesium ion, and the second works to block the vasculature. The absence of research on this fungus and its resistance, the study aimed to find the best ways to establish it using some biological control factors. In order to preserve the environment the most important is to keep the pesticide residue on the fruits because it is very mature and at a time when the decay of pesticides may be slow to fade because they bloom in winter and ripen in the spring.

\section{Materials and methods of work}

\section{2-1 Disease Scan:}

The survey was conducted in a number of cultivated areas in Saladin (Samarra - Samarra University, Balad - Dhuluiya). The areas where the plants were planted were observed. The symptoms were observed. (3) Symptoms include wilting of the leaves and a brown to black area under the foreskin with ulcers and death to branches Samples were collected in the infected trees. The models were placed in nylon bags and fixed with date data collection and percentage of the injury were transferred to the laboratory, and codes were given are(Samarra farms, Balad, the city of Dhuluiya and Samarra University ( BD, SB)

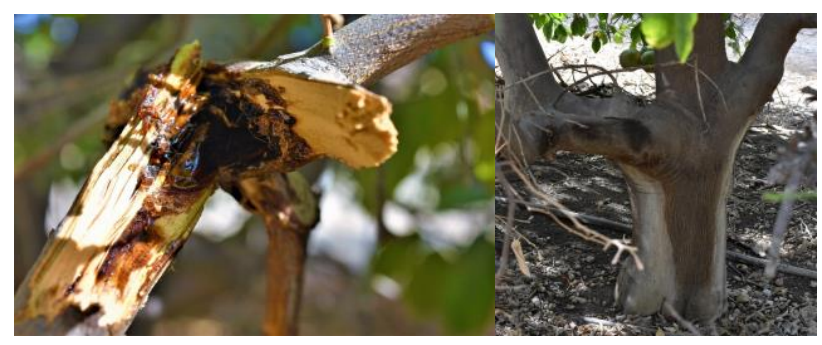

Figure (1) Symptoms of Henderson wilt 


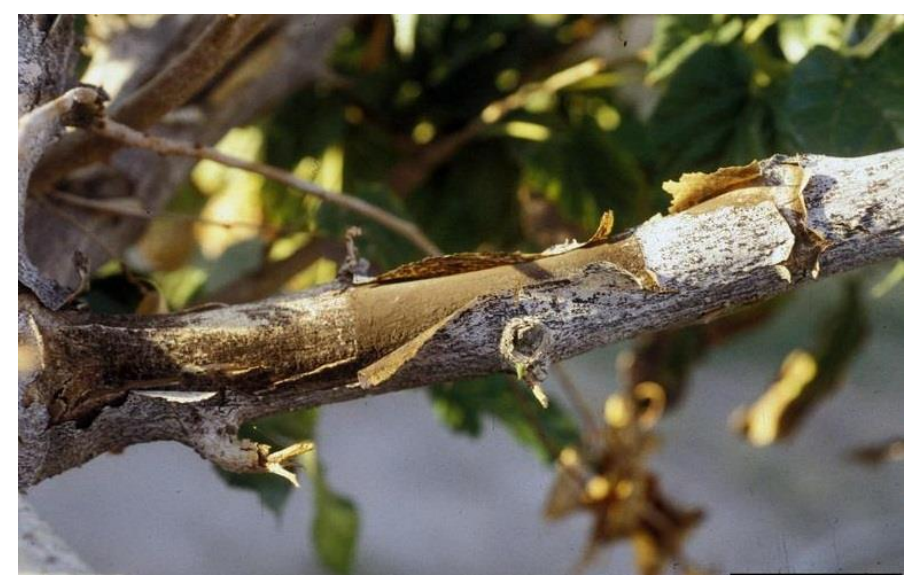

Figure (2) Signs of the pathogen on the tree branch

\section{2-2 Insulation and diagnosis:}

Three samples were collected from the Ficus plant for direct inspection. The plant parts were cut into small pieces of $0.5-0.25 \mathrm{~cm}$, washed with running water for half an hour and sterilized by immersing them for 2 minutes in $1 \%$ sodium hypochlorite solution and then washed with sterile distilled water. Three pieces were grown in each 9-cm-diameter container, each $20 \mathrm{~cm} 3$ of the Potato Dextride Agar (PDA) medium medium, supplemented with $50 \mathrm{mg} / \mathrm{L}$ with 25-dish / streolomycin sulfate. The dishes were incubated at $(27-25 \mathrm{~m})$ for five days after isolating the isolates and performed the diagnosis using the classification key prepared by (5).

\section{2-3 Test the pathogenesis of fungi}

The test was carried out according to method (10) by selecting branches of the non-infected Ficus plant with length of $15 \mathrm{~cm}$ and diameter $3-5 \mathrm{~cm}$. It was $1 \mathrm{~cm}$ long and $2 \mathrm{~mm}$ deep. It was contaminated with a vaccine from the colony of fungi at 5 days and by 3 branches $\mathrm{x} 3$ bis. And the results were calculated by calculating the average increase in the length of ulceration in the branch and the stiffness of the leaves after 72 hours of contamination. The experiment was designed according to the full design and the disease was monitored for 30 days of vaccination.

Duration of the evaluation of the efficiency of some biological factors in reducing the injury of the Ficus plant infected with fungus Hendersonula toruloidea under the conditions of the plastic house: The results were calculated by calculating the average increase in the length of branching.

The experiment was carried out in one of the greenhouses in a nursery in the city of Samarra by taking two year old seedlings planted in $25 \mathrm{~cm}$ and $2 \mathrm{~kg}$ of soil planted with sterile soil. The experiment included four replicates, as follows:

.Individually isolating Hendersonula toruloida.1- 


\section{.2- Isolation of Hendersonula toruloidea + Biofruit Trichoderma harzianum}

)Biodegradability was obtained from the laboratories of the Ministry of Science and Technology). The antibiotic resistance against the fungus was tested using the double implant method and gave us the highest antibody (11).

.Heter sonula toruloida + bacterial Bacillus subtilis.3-

(Bacteria were also isolated from the laboratories of the Ministry of Science and Technology) and are classified as (4).

The highest fungal inhibitor was determined according to 14

.Treatment of comparison is not treated with any living organism.4-

Vaccines were added as follows:

The tortuloidea $H$. vaccine was added to a three-dish suspension filled with fungus and was mixed well after the addition of sterile distilled water to a 2-liter volume, mixed with a mixing device, the plants were fertilized and washed according to Wilson's method. fungi T. harzianum was added in suspension form $4 \times 610 \mathrm{pg} / \mathrm{mL}$ (The conidial suspension was prepared after the growth of the fungus in the dish was completed. $10 \mathrm{ml}$ of distilled water was added to it, then 1 $\mathrm{ml}$ of the suspension was taken to a tube containing $1 \mathrm{ml}$ of distilled water until it reached a dilution $6^{10}$ ) with vegetative total and watering plants. $16 \mathrm{~B}$. subtilis vaccine was added with 7.5 $\mathrm{ml}$ of bacterial suspension taken from a 3 day old farm (20) at a concentration of $5 \times 910$ (colony formation unit / $\mathrm{ml})$.

The experiment was designed according to the RCBD design, with three replications

\section{Results and discussion}

\section{3-1 Percentage of branch wilt disease on trees:}

Table (1) Percentage of branch wilt disease for surveyed areas:

\begin{tabular}{|l|l|l|l|}
\hline \multicolumn{2}{|c|}{ Region } & Ficus plants Individual farming & Ficus plants Mixed farming \\
\hline Samarra & $\begin{array}{l}\text { Samarra } \\
\text { university }\end{array}$ & 55 & 27 \\
\hline Balad & Dhulo'aia & 57 & 26 \\
\hline
\end{tabular}

The results of the first table showed a difference in the severity of infection between plants grown alone from plants in mixed cultivation. The severity of infection in mixed cultivated areas 
at the University of Samarra reached 55\%, followed by fields in the city of Samarra, while in Balad city in monoculture it was less infected, as it reached $26 \%$. This decrease may be due to service, fertilization and irrigation, as well as avoid direct exposure to sunlight and environmental stress factors. Therefore, we observe the lack of cracks in the branches and increase their resistance to fungi. (1)

\section{3-2 Insulation and diagnosis}

The results of isolation from the branches and branches of the host (Ficus) in the direct way from under the skin, there are indicators based on the growth and form H. Torulodea, where they appeared under the microscope series of branches of articulated spores in brown color. The colonies appear in white gray and then darken to the dark green. Over time, the color becomes black as a result of its transformation into spores. The growth appears in a single way, and this is similar to that of $H$. troulodea. Installed by (9) and (17). The isolated fungus showed a pathogenic ability to the branches and leaves of the ficus plants affected by the wilt of the generative branches when developing on the middle of the PDA in its mystic and light cotton and transparent color, which quickly turns into olive color then dark black.

The diameter of the colony was $9 \mathrm{~cm}$ after 5 days of incubation at $1+29^{\circ} \mathrm{C}$ and microscopic examination. It was explained that the fungal spores of the fungus consisted of daring the innate isolation into the multiple-cell arthrospore cells.

The colony appeared in the first days with a light cotton appearance and a color close to transparent, then turning to dark olive then black. The fungus appears under the microscope in the form of conidia chains linked to each other, multiplying by fragmentation into multi-septal cells 2.5-9 x $3.5 \mu \mathrm{m}$ These qualities are very similar to what was proven by the scientists ( Hunter and Barnett, 1972) So are the two scientists /(Dyko and Sutton, 1989) (19); (8)

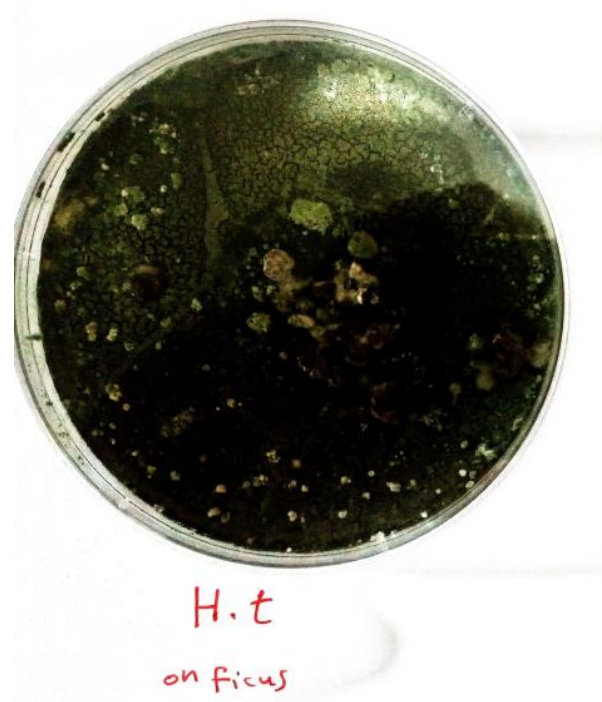


Figure (3) The colony is shown in dark olive color

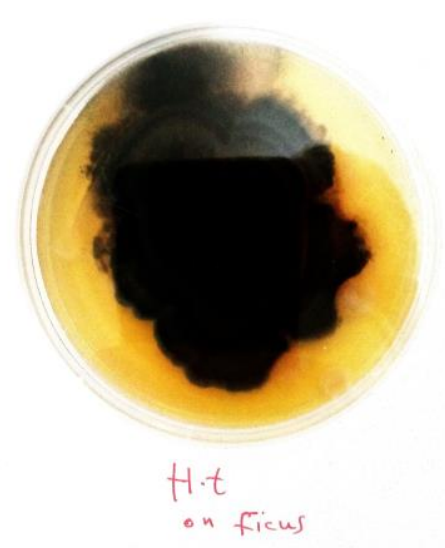

Figure (4) The colony appears in black after 3 weeks

After the industrial infection of the branches of the plant healthy 60 days showed isolated isolates the ability of parasitic fungi of the branches and showed symptoms of wilting branches and ulceration accompanied by a dark color of the infected tissue with dry dandruff and ease of disintegration and these symptoms match the symptoms of the fungus $H$. troulodea. This confirms what has been stated.

The results of the isolating of the samples of cultivated areas (Balad) and (Samarra) showed the presence of one fungus that appeared in all the $100 \%$ pieces. They all grew on the same plant medium at approximately speed and type and the fungal thread as well as Conidia spores as well as fragmentation into cells Multiple Arthrospore barriers.

\section{3-3 Pathogenicity tests}

Table (2) Effect of $\mathbf{H}$. fungi on the growth of Ficus after 45 days of infection

\begin{tabular}{|l|c|}
\hline Trearment type & \% Severity of infection \\
\hline class S / samarra / UOS & 82 \\
\hline class B / balad / Dhulo'aia & 74 \\
\hline comparison & 0.0 \\
\hline LSD) 5(\%) & 17 \\
\hline
\end{tabular}

The study showed that there were no significant differences at the level of error 0.05 in the disease susceptibility of isolates tested. The severity of the isolates was SB, 82\% and B.D, 74\% 
respectively, while the severity of the infection was $0.0 \%$. Based on the length and color of the ulcers and the wood we can say that there is no specialization for the infection of mushrooms and this is due to the possession of fungus wide family extent The data of this study in accordance with the reference to both (19) and (21)

\section{3-4 Evaluation of the efficiency of biocontrol agents}

Table (3) The effect of biological resistance factors on the rate of infection with pathogenic fungi

\begin{tabular}{|l|l|}
\hline Factors & infection rate\% \\
\hline T. harizainum+ H. toruloidea & $\mathbf{2 5}$ \\
\hline B subtilis & $\mathbf{4 0}$ \\
\hline control & $\mathbf{9 0}$ \\
\hline LSD) 5(\%) & $\mathbf{1 2}$ \\
\hline
\end{tabular}

he results of table 3 of this study showed that the biological resistance treatments provided good protection for the fungus plants of the fungus $H$ torulidea. And significantly reduced $\mathrm{p}<0.05$ ) in the severity of the disease of the branches of the Hendrini branch compared to the treatment of the comparison under the conditions of the plastic house compared to the comparison treatment contaminated with isolating fungus DT (isolated isolation) alone. The use of T. harizianum with the presence of $H$. toruloidea and $B$. subtilis with $H$. toruloidea reduced the severity of the infection to $25 \%$ and $40 \%$ respectively. while the severity of infection with the fungal infection was $90 \%$. This result was identical and proved the effectiveness of the fungus against many fungi as stated (23 - 25 and 26). Where the fungus T. harzianum is a colony around the roots, which works to increase the size of the root total and increase its hardness and mechanisms of action of fungus is parasitism and antibiotic 27 , and also caused B. subtilis bacteria significantly reduced the severity of infection and the presence of fungus to $10 \%$ What he found (3) of these efficacy on pathogenic fungi and on different crops.

The efficacy of these bacteria may have been due to their ability to compete with pathogenic fungi for food and root secretions, thus making the environment unsuitable for the disease through the release of antibiotics such as Bacilin and Bacilomycin, which decomposes and determines the cytoplasmic filaments.

Table (4) Effect of different treatments on dry vegetative weight

\begin{tabular}{|l|l|}
\hline Experience factors & The increase in the dry weight of the vegetative part \\
\hline T. harzianum & $5.6 \mathrm{~g}$ \\
\hline B. subtilis & $3.03 \mathrm{~g}$ \\
\hline Cntrol & $1.3 \mathrm{~g}$ \\
\hline LSD) $5(\%)$ & $0.6 \mathrm{~g}$ \\
\hline
\end{tabular}


The results of Table 4 showed that biogas treated dry weight of vegetative group with pathogenic $T$.harizianum was $5.6 \mathrm{~g} /$ plant whereas all the dry weight of the vegetative group in the treated pollutant was isolated by the fungus extended by $1.3 \mathrm{~g} /$ plant. These results confirm that (2) (1) of the biological control agents' ability to improve plant growth standards.

\section{References}

[1] إبراهيم, بسام يحيى ونضال يونس المراد (2005) • سمية وامراضية الفطر H.toruloidea على أشجار الحمضيات . مجلة زراعة الرافدين 2

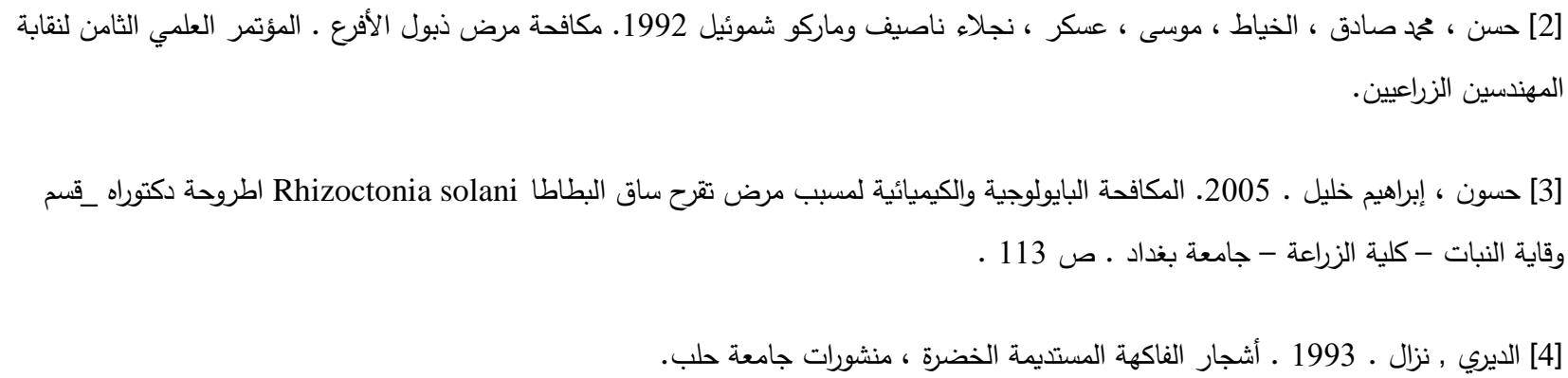

[5] ديوان ، مجيد متعب وحمد حمزة عباس • 2001. مقاومة مرض تعفن البذور وموت بادرات الحنطة المتسبب عن الفطر مhizoctonia solani باستخدام الفطر Brichoderma harziamm والمبيد Benlate حقلياً . المؤتمر العلمي القطري الأول لوقاية المزورعات ـ بغداد 5 - 11 نيسان . [6] القصاب ، عبد المطلب رضا حيدر (1986) • تتقية وتثخيص السموم التي يفرزها الفطر Hendersonula toruloidea Nattrass ، رسالة ما جستير ، كلية العلوم • جامعة صلاح الدين - أربيل .

[7] المراد ، نضال يونس .2006.تسجيل أول لمرض ذبول الأفرع الهندرسونيولي على أشجار الجنار في العراق ، مجلة الرافدين 4 (33) : 316 - 327

[8] AL-Hassan, K.K., AL-Hassan, S.A., Mustaffa, F.H. 1970. Branch wilt of Apple in Iraq. FAO. Bull.(5). 18:115118 .

[9] Hendersonula toruloidea Nattrass in Ninevah, Iraq Mesopotamia J. Agric. 14:99-106 .

[10] Johannes, S., and M. Tschen . 1988 . Control of plant pathogen fungus Rhizoctonia solani by microorganisms. http:// www. Kclc.or. jp / hubold / ostasien / tschen. htm .

[11] Larkin, R. P. 2004 . Development of integrated biological and cultural approaches for control of powdery scab and other soil borne diseases. USDA, ARS, New England, Plant Soil, and Water Lab, Univer. of Maine, Orone, ME 44469 www. Maine potatos. Com / pdf / potresgrant - 04 .

[12] Lo, C.T., E. B. Nelson, and G. E. Harman . 1996 . Biological control of turfgrass disease disease with Rhizosphere competent strain of Trichoderma harzinum plant. Dis 30:736-741

[13] Meredith DS. 1963. Tip rot of banana fruits in Jamaica. I. Hendersonula toruloidea on Dwarf Cavendish bananas. Trans. British Mycol. Soc. 46: 473-481. 
[14] Mirzaee, M.R.; Mohammadi, M.; Rahimian, H. 2002. Nattrassia mangiferae, the cause of die-back and trunk cankers of Ficus religiosa and branch wilt of Psidium guajava in Iran. Journal of Phytopathology 150(4/5): 244-247

[15] Muhammad, S. and A. Amusa. 2003. Invitro inhibition of growth of some seeding blight inducing Pathogens by compost - inhabiting microbs. J. Biotech. $2: 161-164$.

[16] Nattrass RM. 1933. A new species of Hendersonula (H. toruloidea) on deciduous trees in Egypt. Trans. Br. Mycol. Soc. 18:189-198.

[17] Shawkat, A. L. B. Tarabeih A. M., Attrackchi, A. A. and Ahmed, J. M. 1979 . species of populus and pinus sa new host of Handersonula toruloi

[18] Smith, W. H. 1970 . Tree pathology : A short introduction. New York / Academic 309 pp.

[19] Sutton, B.C.\& B.J.Dyko 1989. Revision of Hendersonula.Mycol. Research, 93:466-488.

[20] Tsahouridou PC and Thanassoulopoulos CC. 2000. First report of Hendersonula toruloidea as a foliar pathogen of strawberry-tree (Arbutus unedo) in Europe. Plant Dis. 84: p 487.

[21] Van der Plank J.E. 1960. Analysis os epidemics. In plant Pathology Vol. 3, ed. J.G. Hhorsfall and A.E Dimond. Pp. 229 - 289. New York / Academic .

[22] Wilson, E.E. 1947. The branch wilt of Persian walnut trees and its cause. Hilgardia 17:413-430. 